\title{
The Tertiary: a proposal for its formal definition
}

1 Department of Earth Sciences, Brock University, 500 Glenridge Avenue, St. Catharines, Ontario L2S 3A1, Canada.Email: mjhead@brocku.ca 2 Cambridge Quaternary, Department of Geography, University of Cambridge, Downing Place, Cambridge CB2 3EN, United Kingdom.

3 Department of Geological Sciences, University of Texas at Austin, Austin, Texas 78712, U.S.A. [Deceased]

The term Tertiary, subdivided into the Paleogene and Neogene, is traditionally used to represent the interval of geological time between the Cretaceous and Quaternary. In the 1990s, however, the Neogene and Paleogene were ratified by the International Union of Geological Sciences as periods/systems of the Cenozoic Era/Erathem, leaving the Tertiary officially undefined. The Tertiary nonetheless remains a formal term that has never been officially eliminated, and its widespread use today implies a long future. To regularise its use, and following the most widely used topology among Cenozoic time scales, the Tertiary is here proposed as a period/system subjacent to the Quaternary and with its base defined by the Global Stratotype Section and Point that marks the base-Danian Age/Stage at c. 65.5 Ma. The Neogene and Paleogene, currently designated as periods, then become sub-periods within the Tertiary. The top of the Tertiary would be defined by the base of the Quaternary at 2.6 Ma. This proposal complies strictly with the hierarchical requirements of the geological time scale, fully accommodates current proposals by the International Commission on Stratigraphy and International Union for Quaternary Research regarding the Quaternary, and respects the historical and widespread current usage of the term Tertiary.

\section{Introduction}

The term Tertiary was originally introduced by Arduino in 1759 as part of his four-fold classification of deposits in the Venetian and Tuscan regions of Italy (Arduino, 1760), and strata he classified as Tertiary are still so regarded today (Vaccari, 2006). The term has been used continuously for more than two hundred years, and affirmed officially by the Paris 1990 International Geological Congress (Vai, 2007). The Tertiary continues to refer to the interval of time between the Cretaceous and Quaternary, and as such is a useful and unambiguous term (Harland et al., 1990) that remains widely used (Salvador, 2006a,b).

The Tertiary is commonly depicted as a period/system in the literature (Salvador, 2006b). However, since 1976, the International Commission on Stratigraphy (ICS) has divided the Cenozoic Era into the Paleogene, Neogene, and Quaternary, treating the Tertiary as a "useful informal term to include both the Paleogene and Neogene' (Cowie and Bassett, 1989; Figure 1). This was foreshadowed by an earlier recommendation by the Stratigraphy Committee of the Geological Society, London, that the Cenozoic be divided informally into Tertiary and Quaternary sub-eras, with the Tertiary subdivided into Paleogene and Neogene periods/systems (George et al.,
1968). This scheme was followed by Curry et al. (1978) and Harland et al. (1982, 1990; Figure 1). Currently, the Cenozoic Era has two formally ratified periods/systems defined by global boundary stratotype sections and points (GSSPs). The Paleogene Period/System was ratified in 1991 by the International Union of Geological Sciences (IUGS) upon acceptance of the basal-Danian GSSP (Molina et al., 2006), and the Neogene Period/System was ratified in 1996 upon the acceptance of the basal-Neogene GSSP (Steininger et al., 1997).

The Tertiary was accordingly absent from the IUGS-sanctioned geological time scales of Cowie and Bassett (1989) and Remane (2000), having been left undefined by the IUGS (Figure 1). The Quaternary was later to experience a similar attempted suppression (Bowen and Gibbard, 2007), although not from the IUGS. In spite of these omissions, the Tertiary has never been explicitly eliminated by the IUGS.

The end of the Tertiary is traditionally defined by the beginning of the Quaternary. The International Union for Quaternary Research (INQUA) and the ICS have recently proposed the Quaternary as a period/system, with its base lowered to the base-Gelasian Age/Stage GSSP at 2.6 Ma. In this proposal, the Gelasian Stage is transferred to the Pleistocene Epoch/Series (Head, Gibbard and Salvador, this issue; and Ogg and Pillans, this issue). It is now timely to assess the rank and duration of the Tertiary. The IUGS has itself acknowledged this need, stating that the Quaternary should be defined with 'due consideration and respect for the issue of the Tertiary' (IUGS correspondence to ICS, May 2007).

\section{Justification of the Tertiary as an official period/system}

Sanctioned by long and precise usage, the Tertiary is already a formal stratigraphic term (Salvador, 2006a). It has never been officially eliminated by the IUGS, but its rank and duration have yet to be defined by GSSPs that would regularise its use. Recent proposals have already addressed this issue (Pillans, 2007).

Aubry et al. (2005; Figure 1) proposed the Tertiary and Quaternary as sub-eras/sub-systems, but their scheme is neither acceptable to most Quaternarists nor meets the IUGS's strict requirements of a hierarchical time scale. Walsh (2006) and Salvador (2006a,b) accepted the Tertiary and Quaternary as eras/systems but followed a $1.8 \mathrm{Ma}$ age for the base of the Quaternary, which again is unacceptable to most Quaternarists and to INQUA and the ICS (Head, Gibbard and Salvador, this issue; Ogg and Pillans, this issue).

Berggren (1998) and Luterbacher et al. (2005) argued that the Quaternary and Tertiary should be abandoned because they are part of an obsolete classification. But if names were discarded merely for this reason, we would lose the Cretaceous and Carbonifeous (Walsh, 2006; Vai, 2007). Unlike Primary and Secondary, the terms Quaternary and Tertiary survived because they were useful; and their etymologies are instructive in recalling the early history of stratigraphic research.

In 2005 , the ICS recommended that the Tertiary not be considered as a formal division of the geological time scale 'because it is nearly redundant with the entire Cenozoic Era' (International Com- 


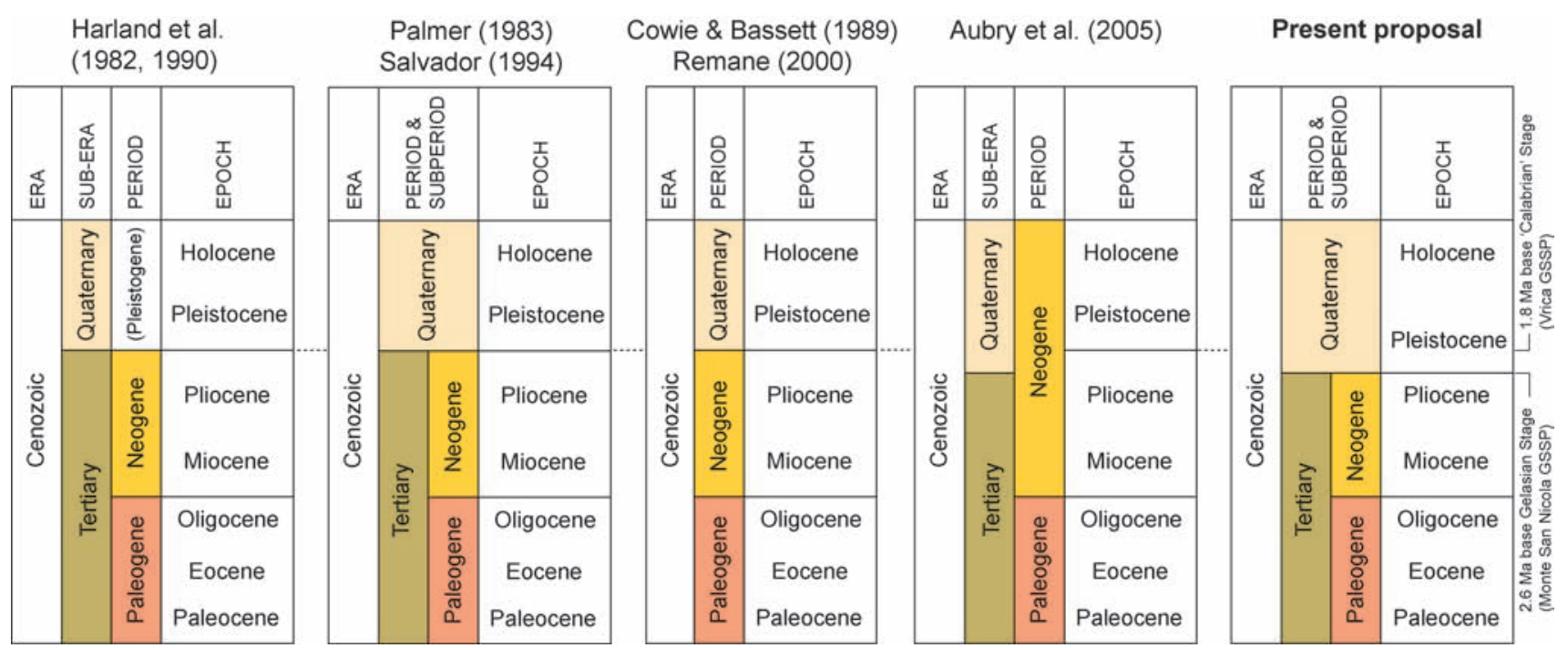

Figure 1 Comparison of Cenozoic time scales. The Palmer (1983) and Salvador (1994) time scale is the most widely accepted Cenozoic time scale in current use (Salvador, 2006b). It is also the preferred option of Walsh (2006, in press), and has been adopted by the US Geological Survey and the Geological Society of America. The time scale by Cowie and Bassett (1989) and Remane (2000) represents the most recent (and current) time scale endorsed by the IUGS. The present proposal adopts the Palmer (1983) and Salvador (1994) time scale except that the Tertiary-Quaternary boundary is lowered to 2.6 Ma in accordance with Head, Gibbard and Salvador (this issue) and Ogg and Pillans (this issue). Intervals of geological time are not to scale.

mission on Stratigraphy, 2005, p. 2-3). But this argument would also apply to the Pleistocene, whose duration almost fully overlaps with the Quaternary (Walsh, 2006). Moreover, the Tertiary has terminated whereas the Cenozoic (and for that matter the Holocene) is ongoing.

The term Tertiary remains used more frequently in stratigraphic publications than either Paleogene or Neogene (Salvador, $2006 \mathrm{a}, \mathrm{b}$ ). Tertiary already appears as a period/system in the vast majority of published time scales, where it is typically subdivided into Paleogene and Neogene sub-periods/sub-systems (Salvador, 2006b). Its use in the literature has not declined in the past 25 years; and its continued use as a period/system by the Geological Society of America, US Geological Survey (U.S. Geological Survey Geologic Names Committee, 2007), and by individual U.S. state and other national geological surveys, illustrates its wide currency (Salvador, 2006a). It is noteworthy that the term Tertiary, and its abbreviation in ' $\mathrm{K} / \mathrm{T}$ boundary', appears throughout the very publication (Molina et al., 2006) that ostensibly suppresses its name. Moreover, it is ironic that the Quaternary, not the Tertiary, should have survived on IUGSapproved time scales, when the Quaternary was the least well treated of Arduino's four orders (Vaccari, 2006).

\section{Proposal to establish the Tertiary as a GSSP-defined period/system}

For the above reasons, and to maintain stability within the Cenozoic time scale, we propose that the Tertiary be treated as an official period/system contiguous with, and subjacent to, the Quaternary Period/System, with its base defined by the GSSP near El Kef, Tunisia. This GSSP already defines the base of the Danian Stage (c. 65.5 Ma; Molina et al., 2006). The Cenozoic, Quaternary, Paleogene and Danian are thus coterminous. In our proposal (Figure 2), the Paleogene and Neogene become sub-periods/sub-systems of the Tertiary, just as the Mississippian and Pennsylvanian enjoy popular use as sub-periods/sub-systems of the Carboniferous. In our scheme, the top of the Tertiary Period/System is defined by the base of the Quaternary Period/System, Pleistocene Epoch/Series, and Gelasian Age/Stage, all of which would share the same GSSP at the baseGelasian dated at $2.588 \mathrm{Ma}$ (Rio et al., 1998). As a technicality, this would require de-ratifying the Paleogene and Neogene as periods/systems, and re-ratifying them as sub-periods/sub-systems.
Present proposal

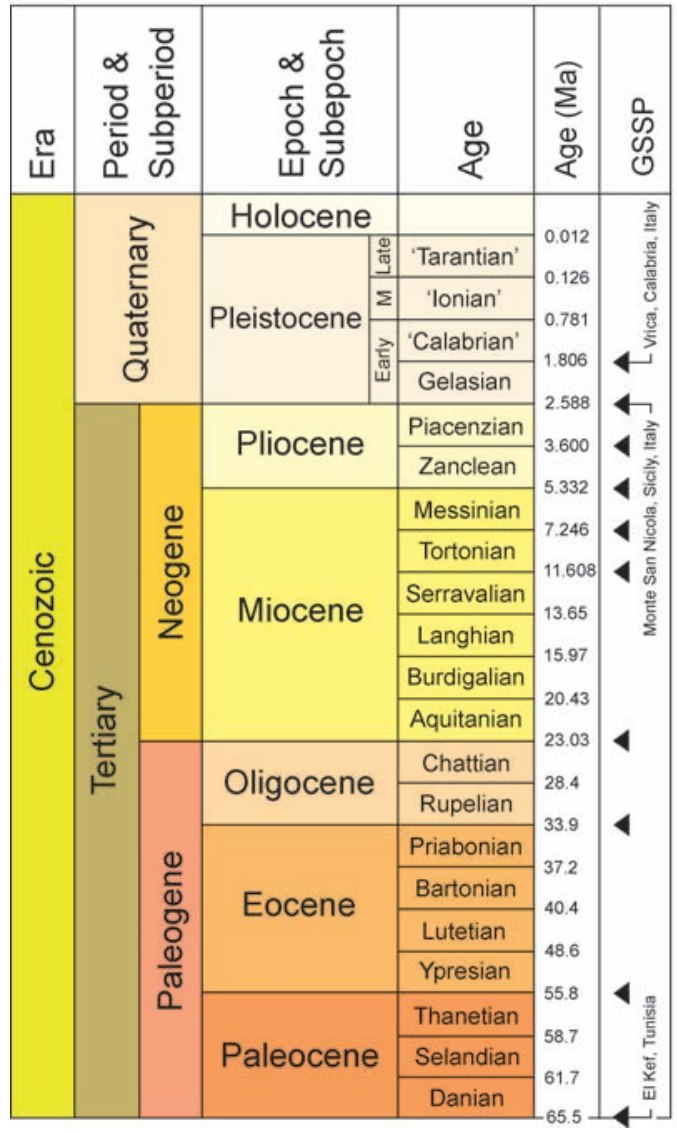

Figure 2 The present proposal for the Cenozoic time scale. Age names and boundary ages are from the ICS website in January 2008 , with the provisional Calabrian and Ionian ages following Cita et al. (2006) and the provisional Tarantian Age following Cita (this issue, and references therein). Currently defined GSSPs are indicated by black triangles. Only those GSSPS mentioned in the text are labeled. Intervals of geological time are not to scale. 
The duration of the Tertiary (62.9 Myr) is similar to that of many other periods in the time scale. The Quaternary (2.6 Myr), while obviously shorter, is ongoing. Our proposed scheme (Figure 2) follows the most popular and widely used topology (e.g., Palmer, 1983; Salvador, 1994, 2006a, b; Walsh, 2006, Figure 1B) while accepting the justification for placing the Tertiary-Quaternary boundary at 2.6 Ma (Head, Gibbard and Salvador, this issue; Ogg and Pillans, this issue). Our scheme meets the IUGS requirements of a hierarchical time scale, requires no unusual designations of rank, and respects historical precedents and established usage of the term Tertiary.

\section{Acknowledgements}

This paper is based on a proposal presented at the CANQUA conference in Ottawa, June, 2007 (Head, 2007): MJH is grateful to the organisers for a stimulating meeting. We are pleased to acknowledge helpful comments on the manuscript by Brad Pillans and Jan Piotrowski, and much assistance from Jim Ogg.

\section{References}

Arduino, G., 1760, Sopra varie sue Osservazioni fatte in diverse parti del Territorio di Vicenza, ed altrove, appartenenti alla Teoria Terrestre, ed alla Mineralogia. Letter to Prof. Antonio Vallisnieri, dated 30th March, 1759. Nuova Raccolta di Opuscoli Scientifici e Filologici (Venice), v. 6 (1760).

Aubry, M.-P., Berggren, W.A., Van Couvering, J., McGowran, B., Pillans, B., and Hilgen, F., 2005. Quaternary: status, rank, definition, survival: Episodes, v. 28, pp. 118-120.

Berggren, W.A., 1998. The Cenozoic Era: Lyellian (chrono)stratigraphy and nomenclatural reform at the millennium. In: Blundell, D.J., and Scott, A.C. (eds), Lyell: the past is the key to the present: Geological Society, London, Special Publication, 143, pp. 111-132.

Bowen, D.Q., and Gibbard, P.L., 2007. The Quaternary is here to stay: Journal of Quaternary Science, v. 22, pp. 3-8.

Cita, M.B., Capraro, L., Ciaranfi, N., Di Stefano, E., Marino, M., Rio, D., Sprovieri, R., and Vai, G.B., 2006. Calabrian and Ionian: A proposal for the definition of Mediterranean stages for the Lower and Middle Pleistocene: Episodes, v. 29, 107-114.

Cowie, J.W. and Bassett, M.G. (compilers) 1989. 1989 global stratigraphic chart with geochronometric and magnetostratigraphic calibration: Episodes, 12 (2), supplement, 1 sheet.

Curry, D., Adams, C.G., Boulter, M.C., Dilley, F.C., Eames, F.E., Funnell, B.M., and Wells, M.K., 1978. A correlation of Tertiary rocks in the British Isles: Geological Society, London, Special Report 12, 72 pp.

George, T.N. and 12 others, 1968. International Geological Correlation Programme-United Kingdom contribution-Recommendations on stratigraphical classification: The Royal Society, London, $43 \mathrm{pp}$.

Harland, W.B., Cox, A.V., Llewellyn, P.G., Pickton, C.A.G., Smith, A.G., and Walters, R., 1982. A geologic time scale: Cambridge University Press, Cambridge, i-xi, pp.1-131.

Harland, W.B., Armstrong, R.L., Cox, A.V., Craig, L.E., Smith, A.G., and Smith, D.G., 1990. A geologic time scale 1989: Cambridge University Press, Cambridge, i-xvi, pp.1-263.

Head, M.J., 2007. Tracking the status and duration of the Quaternary - a resolution in sight? CANQUA Annual Meeting: Carleton University, Ottawa, June, 2007.

International Commission on Stratigraphy, 2005. Definition and rank of Quaternary. Unpublished report to the IUGS, 9 pp. (available online at: http://www.stratigraphy.org/).

Luterbacher, H.P., Ali, J.R., Brinkhuis, H., Gradstein, F.M., Hooker, J.J., Monechi, S., Ogg, J.G., Powell, J., Röhl, U., Sanfilippo, A., and Schmitz, B., 2005. The Paleogene Period. In: Gradstein, F.M., Ogg, J.G., and Smith, A.G. (eds.), A Geologic Time Scale 2004: Cambridge University Press, Cambridge, pp. 384-408 [Imprinted 2004].

Molina, E., Alegret, L., Arenillas, I., Arz, J.A., Gallala, N., Hardenbol, J., von Salis, K., Steurbaut, E., Vandenberghe, N., and Zaghbib-Turki, D., 2006. The Global Boundary Stratotype Section and Point for the base of the Danian Stage (Paleocene, Paleogene, "Tertiary", Cenozoic) at El Kef, Tunisia: Episodes, v. 29, pp. 263-273.

Palmer, A.R. (compiler) 1983. The Decade of North American Geology 1983 geologic time scale: Geology, v.11, pp. 503-504.

Pillans, B., 2007. Defining the Quaternary: Where do we go from here?: Stratigraphy, v. 4, pp. 145-149.
Remane, J. (compiler) 2000. International Stratigraphic Chart. International Union of Geological Sciences, and UNESCO Division of Earth Sciences, Paris.

Rio, D., Sprovieri, R., Castradori, D. and Di Stefano, E., 1998. The Gelasian Stage (Upper Pliocene): A new unit of the global standard chronostratigraphic scale: Episodes, v. 21, pp. 82-87.

Salvador, A. (ed.), 1994. International Stratigraphic Guide, second edition: International Union of Geological Sciences, and The Geological Society of America, Inc., Boulder Colorado, i-xix, pp. 1-214.

Salvador, A., 2006a. The Tertiary and the Quaternary are here to stay: AAPG Bulletin, v. 90, pp. 21-30.

Salvador, A., 2006b. A stable Cenozoic geologic time scale is indispensable: Episodes, v. 29, pp. 43-45.

Steininger, F.F., Aubry, M.P., Berggren, W.A., Biolzi, M., Borsetti, A.M., Cartlidge, J.E., Cati, F., Corfield, R., Gelati, R., Iaccarino, S., Napoleone, C., Ottner, F., Rögl, F., Roetzel, R., Spezzaferri, S., Tateo, F., Villa, G., and Zevenboom, D., 1997. The global stratotype section and point (GSSP) for the base of the Neogene: Episodes, v. 20, pp. 23-28.

U.S. Geological Survey Geologic Names Committee, 2007. Divisions of geologic time-Major chronostratigraphic and geochronologic units: U.S. Geological Survey Fact Sheet 2007-3015, 2 p.

Vaccari, E., 2006. The "classification" of mountains in eighteenth century Italy and the lithostratigraphic theory of Giovanni Arduino (1714-1795): Geological Society of America Special Paper 411, pp. 157-177.

Vai, G.B., 2007. A history of chronostratigraphy: Stratigraphy, v. 4, pp. 83-97.

Walsh, S.L., 2006. Hierarchical subdivision of the Cenozoic Era: A venerable solution, and a critique of current proposals: Earth-Science Reviews, v. 78, pp. 207-237.

Walsh, S.L., in press. The Neogene: origin, adoption, evolution, and controversy: Earth-Science Reviews.

Martin J. Head is Professor and Chair-Elect of the Department of Earth Sciences at Brock University. He was previously at the University of Cambridge, and before that spent 14 years at the University of Toronto where he maintains a cross-appointment. He is a member of the ICS Subcommission on Quaternary Stratigraphy, and of its Working Group on the Lower-Middle Pleistocene Boundary. He is also a member of the INQUA Stratigraphy \& Chronology Commission. His interests include Cenozoic stratigraphy and marine palynology. Martin holds a PhD from the University of Aberdeen.

Philip Gibbard is Professor of Quaternary Palaeoenvironments at the University of Cambridge, United Kingdom, and chair of the International Commission on Stratigraphy's Subcommission on Quaternary Stratigraphy. He is also a member, and was formerly Secretary, of the Stratigraphy and Geochronology Commission of INQUA, the INQUA Subcommission of European Quaternary Stratigraphy and the Geological Society of London's Stratigraphy Commission. His research is focused on terrestrial and shallow marine sedimentation, stratigraphy and environmental evolution throughout Europe, but he has also worked in the Arctic, North America and South-East Asia.
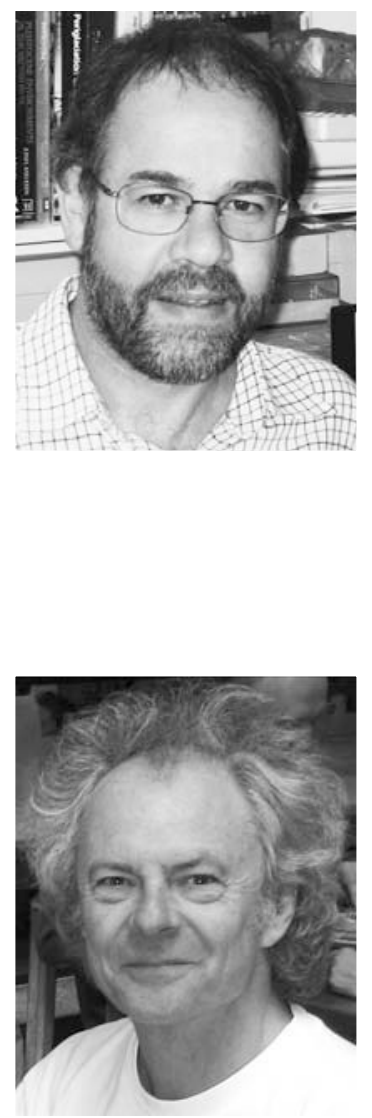